\title{
Factors of China's International Competitive- ness and the Sustainability of its Economy un- der the COVID-19 Pandemic (the Case Study for BRICS)
}

\author{
Tatiana Podolskaya ${ }^{1, *}$ and Maria Singkh ${ }^{1}$ \\ ${ }^{1}$ Russian Presidential Academy of National Economy and Public Administration, South Russia \\ Institute of Management, Rostov-on-Don, Russia
}

\begin{abstract}
The risks and large-scale losses faced by the international community during the COVID-19 pandemic led to a recession in 2020. In these circumstances, of particular interest is the experience of China, which was able to maintain positive economic growth rates, demonstrating a unique resilience to modern challenges. The main objective of the study presented here is a statistical and structural analysis of the factors that ensure China's international competitiveness and the resilience of its economy in the face of the COVID-19 pandemic. The analysis is expected to show which key factors of China's international competitiveness have made its economy resilient to the challenges of the COVID-19 pandemic. The authors also hope to identify which promising developments, similar to China's, will enhance the international competitiveness of the BRICS countries.
\end{abstract}

\section{Introduction}

The COVID-19 pandemic and the restrictions that countries have been forced to impose to combat the spread of the virus have had a very negative impact on the economic development of all countries in the world. IMF experts note that the COVID-19 pandemic has caused "a global crisis unlike any other, causing the worst economic downturn since the Great Depression". The COVID-19 pandemic has already killed more than 2 million people. Despite the unprecedented scale of emergency monetary and fiscal support which, as of September 2020, amounted to about $\$ 11.5$ trillion globally [1], the recession could not be avoided. While the contraction of the global economy in 2020 is estimated by IMF experts at 3.5\% [1], the UN report indicates a more significant decline of $4.3 \%$ [2].

World Bank experts note that the pandemic has exacerbated the risks associated with a decade-long wave of rising debt around the world. Financing government stimulus programs during the pandemic entailed the largest peacetime borrowing, increasing public debt worldwide by 15 percent, i.e. nearly by $\$ 10$ trillion. In addition, it is likely to exacerbate the long-predicted slowdown in potential economic growth over the next decade [3].

\footnotetext{
*Corresponding author: podolskayat@uriu.ranepa.ru
} 
The only national economy in the world that has maintained a positive rate of economic development in the current difficult conditions of the COVID-19 pandemic is China, which was the first to face the spread of the virus. But the stringent measures implemented in China have not only made it possible to quickly contain the spread of the COVID-19 virus, but also to demonstrate the unique resilience of the national economy to modern threats. Thus, based on the results of 2019, when China was the first to face the pandemic, economic growth was $6.1 \%$ and $2.4 \%$ in 2020 [4], the beginning of which was accompanied by the introduction of a hard lockdown first in Wuhan and then in several other territories of the mainland. These indicators show a significant margin of safety for China's economy based on its established competitive advantages in the global economy. China's economy at the beginning of the COVID-19 pandemic was predicted to experience the greatest decline as a country at high risk of country-wide spread of the virus due to its high population density and large number of people. In practice, the situation turned out to be the opposite - China was the only country with positive economic development by the end of 2020. Therefore, it is important to determine the factors underlying the sustainability and international competitiveness of the Chinese economy in order to replicate this experience in the economies of other BRICS countries.

The main purpose of our research is, on the basis of statistical and comparative analysis, to identify the key factors that ensure the international competitiveness of the economy of China as the only state that has maintained positive economic growth rates during the COVID-19 pandemic in order to adjust measures to improve the international competitiveness of BRICS countries. To achieve this purpose, the following research tasks have been formulated:

- To carry out retrospective analysis of the level of international competitiveness of China in comparison with other BRICS countries for the period from 2013 to 2019;

- Based on structural analysis, to highlight the key factors of China's international competitiveness that ensure sustainable economic growth even in the face of the COVID-19 pandemic, compared to the performance of the BRICS countries;

- To identify key areas of China's development that ensure the sustainability of economic development and international competitiveness of the country, which have the potential to increase the international competitiveness of the BRICS countries.

\section{Literature review and theoretical background of the research}

Constant strengthening of international competition and fierce struggle for sales markets under conditions of dynamic scientific and technological development actualizes the issue of ensuring international competitiveness of national economies. The international competitiveness of a state is determined by the extent to which a country's economy can, under conditions of free competition, produce goods and services that meet the demands of the world market, while maintaining or increasing the rate of economic development. Under the COVID-19 pandemic, it turned out that the combination of factors shaping the international competitiveness of China's economy allowed this state to become the only one in the world economy to maintain positive rates of economic development.

The World Economic Forum defines competitiveness as "a set of institutions, policies, and factors that determine a country's level of productivity. The level of productivity, in its turn, sets the sustainable level of economic development which can be ensured by the economy" [5]. Thus, the factors of international competitiveness underlie the modern sustainable economic development of a state.

The World Economic Forum's (WEF) reports (The Global Competitiveness Report (GCR)) [6-12] served as the basis for the study of the key factors underlying the international competitiveness of China's economy. When assessing the level of 
international competitiveness of the country, WEF experts use statistical data and information obtained in the process of interviewing executives of major companies. The Global Competitiveness Report series have been published by WEF since 1979 and the applied methodology is considered the most optimal and containing a full set of indicators of competitiveness of national economies [13].

The Global Competitiveness Index (GCI) in the WEF assessment includes many factors (a total of 103 indicators are used to calculate the index), which are grouped into 12 groups - the main drivers of labor productivity. These groups make up four subindices:

Subindex "Enabling Environment" uniting the following groups: Institutions, Infrastructure, ICT Adoption, and Macroeconomic Stability;

Subindex "Human capital" including the following groups: Health and Skills;

Subindex "Markets" uniting the following groups: Product Market, Labor Market, Financial System, Market Size;

Subindex "Innovation Ecosystem" including the following groups: Business Dynamism and Innovation.

China's experience of providing international competitiveness will be most relevant to the BRICS economies. BRICS is an informal interstate association that includes Brazil, Russia, India, and South Africa in addition to China. The term BRIC was coined by Jim O'Neill, head of global economic research at the U.S. financial-investment company Goldman Sachs, in 2001 as a unification of economies that have begun to exert increasing influence on the economy due to the significant total GDP and its high growth rate. In addition, in 2003 Goldman Sachs on the basis of the long-term forecast, came to the conclusion that by 2050 they should dominate the world and exceed the total size of their economies of the six leading Western economies (then "Group 6" countries - the U.S.A., Japan, Great Britain, Germany, France, and Italy). Due to the accession of South Africa to the BRIC in December 2010, the group became known as the BRICS.

The analysis of China's international competitiveness factors in the presented research is compared with those of the BRICS countries, which seems more adequate, since all countries belong to the group of "emerging market economies". Comparing the international competitiveness of national economies of different groups ("developed countries" and "emerging market economies") requires additional consideration of very different conditions. For example, since Singapore's GDP per capita (GDP per capita), which ranks first in the GCI 2019, is 64,041.4 US\$, while China's is 6.5 times lower at just $9,608.4$ US\$, the standards of medical care, social security and a number of other indicators will differ radically.

The United Nations, IMF, World Bank, World Intellectual Property Organization and World Economic Forum reports published in 2020 and 2021 were used as sources of statistical data for analysis and identification of the most relevant development trends during the COVID-19 pandemic $[14,15,16,17,18]$.

\section{Results}

Despite the very difficult conditions for the development of national economies during the period of total imposition of restrictive measures due to the spread of the COVID-19 virus, the UN forecasts that only the Chinese economy of all the countries of the world will maintain a positive economic growth rate of $2 \%$ both at the end of 2020 and within the forecast estimate for 2021. According to the data presented in Table 1, we can assess how much the trajectory of economic development of the Chinese economy and national economies of other countries around the world diverge. Thus, the average level of economic deceleration of advanced economies in 2020 was $5.4 \%$, and for the BRICS countries (excluding China) it was $6.47 \%$. This testifies to the enormous margin of safety 
of its economy, which have remained resistant to such a global challenge as the COVID-19 pandemic, while the developed countries of the world are not only unable to suppress the spread of COVID-19 organizationally, but also incur heavy economic losses, slipping into recession.

Table 1. Real GDP (percent change from previous year), 2020-2022 (Source: World Economic Situation and Prospects, 2021).

\begin{tabular}{|l|c|c|c|c|c|}
\hline \multirow{2}{*}{} & \multicolumn{4}{|c|}{} & \multicolumn{2}{c|}{$\begin{array}{c}\text { Percentage point differences from } \\
\text { June 2020 } \\
\text { projections }\end{array}$} \\
\cline { 2 - 7 } & $\mathbf{2 0 2 0}$ & $\mathbf{2 0 2 1 f}$ & $\mathbf{2 0 2 0 f}$ & $\mathbf{2 0 2 1}$ & $\mathbf{2 0 2 0}$ \\
\hline World & $\mathbf{- 4 . 3}$ & $\mathbf{4 . 0}$ & $\mathbf{3 . 8}$ & $\mathbf{0 . 9}$ & $\mathbf{- 0 . 2}$ \\
\hline $\begin{array}{l}\text { Advanced } \\
\text { economies }\end{array}$ & -5.4 & 3.3 & 3.5 & 1.6 & -0.6 \\
\hline USA & -3.6 & 3.5 & 3.3 & 2.5 & -0.5 \\
\hline Euro area & -7.4 & 3.6 & 4.0 & 1.7 & -0.9 \\
\hline Japan & -5.3 & 2.5 & 2.3 & 0.8 & 0.0 \\
\hline Brazil & -4.5 & 3.0 & 2.5 & 3.5 & 0.8 \\
\hline China & $\mathbf{2 . 0}$ & $\mathbf{7 . 9}$ & $\mathbf{5 . 2}$ & $\mathbf{1 . 0}$ & $\mathbf{1 . 0}$ \\
\hline India & -9.6 & 5.4 & 5.2 & -6.4 & 2.3 \\
\hline South Africa & -7.8 & 3.3 & 1.7 & -0.7 & 0.4 \\
\hline Russia & -4.0 & 2.6 & 3.0 & 2.0 & -0.1 \\
\hline
\end{tabular}

Note: $\mathrm{e}=$ estimate; $\mathrm{f}=$ forecast.

A retrospective analysis of The Global Competitiveness Report data for the period from 2013 to 2019, presented in Table 2, shows that China's economy maintained its 28th place in the ranking throughout the entire period under review (with the exception of GCR-20132014, where China had 29th place). All other BRICS countries did not show such a stable position according to the Global Competitiveness Index.

Table 2. Global Competitiveness Index (GCI) of BRICS, 2013-2019 (Source: Global Competitiveness Report 2013-2014, 2014-2015, 2015-2016, 2016-2017, 2018, 2019).

\begin{tabular}{|c|c|c|c|c|c|}
\hline $\begin{array}{c}\text { GCI 2013- } \\
\mathbf{2 0 1 4}\end{array}$ & $\begin{array}{c}\text { GCI 2014- } \\
\mathbf{2 0 1 5}\end{array}$ & $\begin{array}{c}\text { GCI 2015- } \\
\mathbf{2 0 1 6}\end{array}$ & $\begin{array}{c}\text { GCI 2016- } \\
\mathbf{2 0 1 7}\end{array}$ & GCI 2018 & GCI 2019 \\
\hline China (29) & China (28) & China (28) & China (28) & China (28) & China (28) \\
\hline India (60) & Russia (45) & Russia (45) & India (39) & Russia (43) & Russia (43) \\
\hline $\begin{array}{c}\text { South } \\
\text { Africa (53) }\end{array}$ & $\begin{array}{c}\text { South Africa } \\
(49)\end{array}$ & India (55) & Russia (43) & India (58) & India (68) \\
\hline Brazil (56) & India (55) & $\begin{array}{c}\text { South Africa } \\
(49)\end{array}$ & $\begin{array}{c}\text { South Africa } \\
(47)\end{array}$ & $\begin{array}{c}\text { South Africa } \\
(67)\end{array}$ & $\begin{array}{c}\text { South } \\
\text { Africa (60) }\end{array}$ \\
\hline Russia (64) & Brazil (75) & Brazil (75) & Brazil (81) & Brazil (72) & Brazil (71) \\
\hline
\end{tabular}

A structural analysis of the key factors of global competitiveness in 2019 (Table 3) reveals that China ranks first among the BRICS countries in eight groups of indicators. Another three groups of indicators, the main drivers of labor productivity (Institutions, Skills, and Financial System), rank China second among the BRICS countries, and only one group of indicators ranks third ("Labor Market").

This is fundamentally different from the situation observed within the BRICS international competitiveness indicators in 2017. At that time, the distribution of places within the BRICS group by subindices and their component indicators indicated that there was no established leadership on the issue of global competitiveness among countries [18].

The realization at the state level that sustainable international competitiveness can be achieved only through the use of modern information society technologies led to the formation of government policy aimed at the systematic development of the high-tech sphere. As a result of these measures, China has transformed from an imitative state into a 
leading developer of information and communication technologies and advanced information standards. The National Intellectual Property Administration of the People's Republic of China (CNIPA) received 1.4 million patent applications. This is twice as many as the United States Patent and Trademark Office (USPTO) received combined. Among the top five offices, China's share of the world total has increased considerably over the past ten years from $17 \%$ in 2009 to $43.4 \%$ in 2019 [16]. At the same time China came in second place on the indicator "Research institutions prominence", 13th place on the indicator "Scientific publications" and 25th place on the indicator (the number of companies implementing breakthrough ideas) "Companies embracing disruptive ideas" in GCR-2019. The high availability of venture capital availability (13th place) and borrowed funds for the private sector "Domestic credit to private sector" (8th place) give an additional impetus to the innovative development of the Chinese economy.

Table 3. BRICS global competitiveness factors (place among 141 states) (Source [7]).

\begin{tabular}{|c|c|c|c|c|c|}
\hline \multirow{2}{*}{$\begin{array}{c}\text { Indicators of } \\
\text { Global } \\
\text { Competitiveness } \\
\text { Index }\end{array}$} & \multicolumn{5}{|c|}{ BRICS countries } \\
\hline & $\begin{array}{l}1^{\text {st }} \text { place } \\
\text { among } \\
\text { BRICS }\end{array}$ & $\begin{array}{c}2^{\text {nd }} \text { place } \\
\text { among } \\
\text { BRICS }\end{array}$ & $\begin{array}{c}3^{\text {rd }} \text { place } \\
\text { among } \\
\text { BRICS }\end{array}$ & $\begin{array}{l}4^{\text {th }} \text { place } \\
\text { among } \\
\text { BRICS }\end{array}$ & $\begin{array}{c}5^{\text {th }} \text { place } \\
\text { among } \\
\text { BRICS }\end{array}$ \\
\hline \multicolumn{6}{|c|}{ Subindex «Enabling Environment» } \\
\hline Institutions & $\begin{array}{c}\text { South Africa } \\
(55)\end{array}$ & China (58) & India (59) & Russia (74) & Brazil (99) \\
\hline Infrastructure & China (36) & Russia (50) & $\begin{array}{c}\text { South } \\
\text { Africa (69) }\end{array}$ & India $(70)$ & Brazil (78) \\
\hline ICT adoption & China (18) & Russia (22) & Brazil (67) & $\begin{array}{c}\text { South } \\
\text { Africa (89) }\end{array}$ & India (120) \\
\hline $\begin{array}{l}\text { Macroeconomic } \\
\text { stability }\end{array}$ & China (39) & \multicolumn{2}{|c|}{ Russia and India (43) } & $\begin{array}{c}\text { South } \\
\text { Africa (59) }\end{array}$ & $\begin{array}{l}\text { Brazil } \\
(115)\end{array}$ \\
\hline \multicolumn{6}{|c|}{ Subindex «Human capital» } \\
\hline Health & China (40) & Brazil (75) & Russia (97) & India (110) & $\begin{array}{c}\text { South } \\
\text { Africa } \\
(118)\end{array}$ \\
\hline Skills & Russia (54) & China (64) & $\begin{array}{c}\text { South } \\
\text { Africa (90) }\end{array}$ & Brazil (96) & India (107) \\
\hline \multicolumn{6}{|c|}{ Subindex «Markets» } \\
\hline Product market & China (54) & $\begin{array}{c}\text { South } \\
\text { Africa (69) }\end{array}$ & Russia (87) & India (101) & $\begin{array}{l}\text { Brazil } \\
(124)\end{array}$ \\
\hline Labor market & Russia (62) & $\begin{array}{c}\text { South } \\
\text { Africa (63) }\end{array}$ & China (72) & India (103) & $\begin{array}{l}\text { Brazil } \\
(105)\end{array}$ \\
\hline Financial system & $\begin{array}{c}\text { South Africa } \\
\text { (19) }\end{array}$ & China (29) & India (40) & Brazil (55) & $\begin{array}{c}\text { Russia } \\
(95)\end{array}$ \\
\hline Market size & China (1) & India (3) & Russia (6) & Brazil (10) & $\begin{array}{c}\text { South } \\
\text { Africa (35) }\end{array}$ \\
\hline \multicolumn{6}{|c|}{ Subindex «Innovation Ecosystem» } \\
\hline Businessdynamism & China (36) & Russia (53) & $\begin{array}{c}\text { South } \\
\text { Africa (60) }\end{array}$ & Brazil (67) & India (69) \\
\hline Innovation & China (24) & Russia (32) & India (35) & Brazil (40) & $\begin{array}{c}\text { South } \\
\text { Africa (46) }\end{array}$ \\
\hline
\end{tabular}

The implementation of large-scale infrastructure projects has made a significant contribution to the sustainability of international competitiveness indicators. But if in the past China's infrastructure investment was mainly focused on railroads, highways and airports, which made it the No. 1 in Liner shipping connectivity, No. 2 in Airport connectivity and No. 10 in Road connectivity. Then, under the influence of the COVID-19 pandemic, China has moved more actively towards the digital economy and accelerated the 
adoption of the $5 \mathrm{G}$ communications standard and technologies such as artificial intelligence, industrial Internet and Internet of Things (IoT) in the commercial sector [19]. The sustainability of economic development and international competitiveness requires not only the creation but also the use of new infrastructure. Its undoubted advantage is that it itself is capable of creating and meeting demand. With domestic demand, including services, reaching its peak and global market demand falling due to the recession, China needs to shift to sustainable consumption patterns. And the new infrastructure can not only lead to the transformation and development of traditional industries, but also affect their long-term development.

An example of the demand for 5G technology during the COVID-19 pandemic in China was the widespread use of telemedicine, which has enabled healthcare professionals to have less contact with patients, identify infected people more quickly, diagnose and treat patients more effectively, track contacts and monitor them effectively. The dynamic development of China's digital economy will create a prerequisite for sustainable economic growth and increased international competitiveness.

Some aspects of labor market development remain a serious unresolved problem in China. According to such indicators as "Redundancy costs" (116th place), "Flexibility of wage determination" (100th place) and "Workers, rights" (93rd place), China's competitive position in the global economy is significantly weaker than that of other BRICS countries.

The rise in living standards of the Chinese population in recent years (the disposable income per capita in China doubled in 2020 compared to 2010) has not yet ensured the development of the social sphere, which would correspond to the successes achieved in the field of economic development. For example, China ranks only 128th out of 141 countries on the "social capital" indicator. But, taking into account that China ranks 1st in the world by the number of population, which at the beginning of 2021 is 1402.5 million people [4], the objective limitation of the operative solution of problems in these spheres is the number of population.

\section{Findings and recommendations}

Based on the results of this analysis, it should be noted that the implementation of infrastructure projects is a priority for all BRICS countries. All BRICS countries are located on large territories, together occupying $26 \%$ of the Earth's land. The creation of modern transport infrastructure will increase the mobility of the workforce, the availability of educational and other services, the provision of which is concentrated in urban centers, and create a prerequisite for solving the problems of uneven territorial development of the countries. For Russia, where the problem of bad roads is traditionally a national problem, the experience of China, where roads are built at a speed of 750 meters per hour, is indeed of particular interest.

The development of new infrastructure for the implementation of the $5 \mathrm{G}$ communications standard and technologies such as artificial intelligence, industrial Internet and Internet of Things in the commercial sector will create the preconditions for China's international competitiveness and, if the BRICS countries move in the same direction, will form the prerequisites for the sustainable economic development of their economies. As the experience of development after previous global crises has shown, countries that actively invested in their development during the downturn in the world economy have recovered at a much higher rate.

The influence of the technological and innovative factors of modern economic development on international competitiveness cannot be overestimated at present. India, following China, is transforming the structure of its national economy by widely introducing innovations, while the success of the other BRICS countries is much more 
modest. Amid the sharp decline in investment due to the COVID-19 pandemic, the BRICS states should prioritize even more clearly and invest more quickly in the development of the digital economy, as China is doing. The transition to the Fourth Industrial Revolution announced by the experts of the World Economic Forum [20,21] will make the construction of the digital economy a key factor in ensuring long-term international competitiveness.

\section{References}

1. Policy Support and Vaccines Expected to Lift Activity (World Economic Outlook Update, 2021)

2. World Economic Situation and Prospects (UN, New York, 2021)

3. Global Economic Prospects (World Bank, Washington, DC, 2021)

4. World Economic Situation and Prospects (UN, New York, 2021)

5. K. Schwab, M. Porter, World Economic Forum (Geneva, 2008)

6. Global Competitiveness Report. How to end a lost decade of productivity growth (World Economic Forum, Geneva, 2018)

7. Global Competitiveness Report. How to end a lost decade of productivity growth (World Economic Forum, Geneva, 2019)

8. Global Competitiveness Report 2013-2014 (World Economic Forum, Geneva, 2014)

9. Global Competitiveness Report 2014-2015 (World Economic Forum, Geneva, 2015)

10. Global Competitiveness Report 2015-2016 (World Economic Forum, Geneva, 2016)

11. Global Competitiveness Report 2016-2017 (World Economic Forum, Geneva, 2017)

12. Global Economic Prospects (World Bank, Washington, DC, 2021)

13. L. Gadgieva, The Competitiveness of the economy as the main factor of economic development (Economics and Business: Theory and Practice, 2016)

14. Policy Support and Vaccines Expected to Lift Activity (World Economic Outlook Update, 2021)

15. The Global Risks Report (World Economic Forum, 2021)

16. World Economic Situation and Prospects (UN, New York, 2021)

17. World Intellectual Property Indicators (World Intellectual Property Organization, Geneva, 2020)

18. T. Podolskaya, The EUrASEANs 3 (2017)

19. N. Belova, Russian gazette 19.06.2020 (2020)

20. L. Kitaeva et al., Government and municipal management. Scholar notes 4 (2020)

21. T. Podolskaya, Economic Reforms for Global Competitiveness (IGI-Global, USA, 2017) 